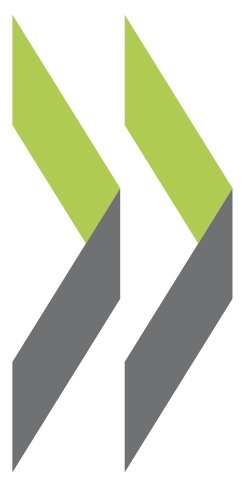

PEB Exchange, Programme on Educational Building 2001/04

\title{
Schools for the 21st
}

Century: Are You Ready?

\section{Prakash Nair}

https://dx.doi.org/10.1787/804472211850 
SCHOOLS FOR THE $21^{\text {ST }}$ CENTURY: ARE YOU READY?

Prakash Nair of the United States proposes the list below for evaluating how a school measures up to the most important requirements of the $21^{\text {st }}$ century. It addresses architects, administors, headteachers, pupils and others responsible for or interested in the design of a new school or the renovation of an existing building.

There are 15 trends happening in the field of education and related educational technology. Many of them have direct facility ramifications. Use them as a checklist to see how many of these trends your school facility is designed to accommodate.

1. Ubiquitous Computing: Leading educators and major school systems in the Unitd States (including New York City which is the country's largest) have accepted the notion that all children from the fourth grade onward should have access to laptop computers and the Internet when they need it, where they need it. This view is endorsed by the US Department of Education which said in a recent report on technology, "Access to technology requires that it be readily at hand for use as needed, not simply for uses that can be predicted in advance and squeezed into a fixed time slot." From a practical standpoint we can assume that students will spend a significant amount of every school day using computers in class. By extension, we can assume that since it is impossible and impractical to put 30 PCs in every room, there will be laptops or some other portable computing device for use in the classroom.

2. Wireless Networking and Robust Internet Access: While it is still a relatively new trend, wireless networking is possibly the one innovation that schools cannot afford to be without. Not only does this bring the Internet and the school network to every child in every room, but also it is now possible to painlessly bring these services to forgotten annexes and "temporary" buildings within the school grounds.

3. Technology-intensive Teaching and Learning: Schools are finally figuring out that computers can redefine not only how to teach, but also what to teach. From a practical standpoint this has resulted in the advent of more project-based and collaborative learning and less lecture-style teaching.

4. Emphasis on Informal Learning: By some measures, less than $25 \%$ of all learning occurs within the classroom. We now know that the socalled "un-programmed spaces" in schools are extremely important because it is in these "nooks and crannies" that much of the socialisation, interaction and real learning take place. Many architects are now building such informal meeting places into the design of schools.

5. De-emphasis of Classrooms: As evident from trends three and four above, the dominance of the classroom as the centre of the learning universe is now in serious jeopardy. Classrooms themselves need to be redesigned so they function well in an environment where self-directed learning and collaborative projects will largely replace "chalk and talk."

6. Food Court vs. Cafeteria: Noted facility planner and writer Paul Abramson recommends that food courts replace school cafeterias. If the poor quality of cafeteria food were not reason enough, students should have greater variety in their diet and be able to eat lunch at their schedule and when they are hungry. Will this create havoc with scheduling the school day? Perhaps, but it is a challenge that institutions of higher learning have already faced and successfully overcome.

7. Shared Common Areas: Reluctantly, and against the protestations of custodial personnel, schools are opening their doors to the community at large. The flip side of the coin is that many new schools are dispensing altogether with traditional auditoriums, gymnasiums and school libraries, choosing to partner instead with local community institutions to create shared common areas and high-quality media centres.

8. Imaginative Furniture Design: This is an obvious area needing improvement where the impact of innovation can be immediate and significant. Fortunately, worktables and computer-friendly furniture including ergonomic desks and chairs are beginning to replace the horrendous desks and tablet armchairs that have unfortunately said "school" more loudly than anything else.

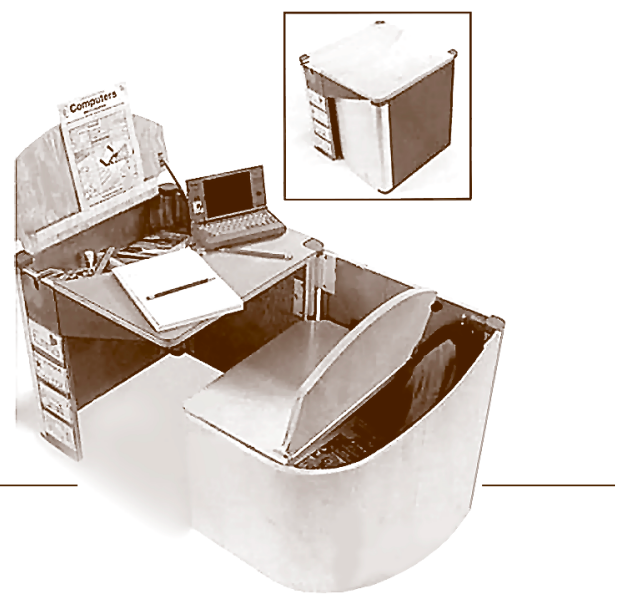


9. Team-teaching, Non-Chronological Grouping and Inter-disciplinary Curriculums: This will call for more flexibility in classroom shapes and sizes including the use of temporary partitions, moveable walls, etc. The old one-size-fits-all approach will severely limit the ability of schools to provide quality $21^{\text {st }}$ century education to their students and deny them the flexibility they need to implement these ideas effectively.

10. Emphasis on Service Learning: More and more schools are requiring students to do some level of community service as part of their graduation requirements. Some schools have structured offsite programmes for students. The impact of this trend is that space will be freed up within schools for varying periods of time during the day. Creatively programming these spaces for the students that remain will be an interesting challenge to both architects and educators.

11. Students Creating Products for Business: The numbers of tech-savvy students are rising each day even as business struggles to fill hundreds of thousands of hi-tech vacancies. Suddenly, business is finding out that partnering with schools goes beyond community outreach and can actually help them financially. For schools, such partnerships, when well managed, bring much-needed revenue and for students it provides the hands-on work experience and financial benefits that beat working in fastfood restaurants. As more students get involved with real-world projects both on and off site, it will be time to rethink equipment, room uses and space configurations in school design.

12. Computer Laboratories Replaced by Distance Learning Electronic Studios: With the advent of wireless laptops, every room and every subject can be taught in a so-called "lab" setting within the primary classrooms. This frees up the traditional computer laboratory for other uses. One logical choice (since laboratories are fully wired and "technology ready") is to convert these old laboratories into distance-learning studios where students can meet and work with experts from around the world. Such rooms can also serve as full-blown presentation "theatres" so that students get to present their work individually and in teams in a professional setting.

13. More Hi-tech Production Facilities: Even as schools adopt a wireless standard, there will be increased demand for high-bandwidth applications like film and video production, broadcast journalism and the exchange of large quantities of data between partnering institutions. Wireless networks will not be ready to handle such data- intensive tasks for several years. In the meantime, schools will need fully wired production facilities where students would work on these kinds of projects. The exact number and design of such facilities will vary by school and the educational programme it offers.

14. Parent and Community Educational Programmes in Schools: Trend number seven touched upon this, but schools are realising that for technology to make a real difference in the life of a child, it is important that its effects be felt at home and in the community. Schools that have tried it find that involving parents and local community members through technology literacy programmes in school is an excellent way to improve their participation in children's education while often improving their economic situation. A properly designed distance learning centre (preferably with monitors recessed inside glass-topped desks) as noted in item 12 above can double as the parent and community training centre in the evenings and when school is not in session.

15. New Learning Partnerships with Other Schools and Universities: Ubiquitous computing and distance learning now make it possible to have real-time communication with a variety of educational partners. For example, District Four in East Harlem, New York City, now routinely runs technology-intensive interdisciplinary projects in which students from various other school districts are invited to participate.

The insular citadel that used to be school is quickly changing to a model where "school" is not just a place, but also a doorway to a lifelong learning experience. The ease with which students will be able to pass through this doorway will determine the success or failure not only of any particular school, but the institution of school itself.

Prakash Nair is the Director of Educational Planning for Vitetta and President of Urban Educational Facilities for the $21^{\text {st }}$ Century (http://www.designshare.com/ uef.htm). He is an internationally recognised expert in the field of school facilities and technology. He welcomes your comments, thoughts and ideas. Please contact him via e-mail at prakash@designshare.com

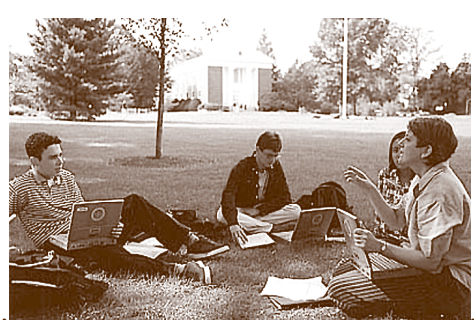

